\title{
Internalization of Character Values in Learning at Institution of English Course
}

\author{
Yuyik Lulita Sari \\ Department of Educational Administration \\ Universitas Negeri Malang, Indonesia \\ yuyik.lulitasarie@gmail.com
}

\author{
Djum Djum Noor Benty \\ Department of Educational Administration \\ Universitas Negeri Malang, Indonesia \\ djum.djum.fip@um.ac.id
}

\author{
Ahmad Nurabadi \\ Department of Educational Administration \\ Universitas Negeri Malang, Indonesia \\ ahmad.nurabadi.fip@um.ac.id
}

\begin{abstract}
The purpose of this study was to describe internalization of character values. This study used a qualitative approach. Data was collected by observation, interview, and documentation studies. The results of the study were: (1) background of internalization, namely the essence of education and business, (2) internalized character values include: religious Islam, responsibility, discipline, independent, clean, neat, friendly, honest, hard work, respect achievement, tolerance, creative, democratic, curiosity, love for the country, love to read, care for the social, caring for the environment, simple, courageous, fair and polite and polite, (3) ways to internalize regulations and sanctions, advice, exemplary, and habituation, (4) support they have in internalizing character values namely warning statement and giving prerogative or authority in the form of expenditure of students who do not want to be regulated.
\end{abstract}

Keywords: internalization, character value, learning, higher education

\section{INTRODUCTION}

A study conducted at Harvard University (in Akbar, 2000) revealed, success is determined only about 20 percent by hard skills and the remaining 80 percent by soft skills. In line with that, the results of a survey conducted by Stanley (in Kurniati, 2007) to 1001 respondents where 733 of them were rich people in America showed, out of 100 lists of success determinants found, being honest to everyone, having good discipline , and good at socializing, sequentially occupying the top 3 positions, while having a high Intelligence Quotient (IQ) and graduating with the best scores appear as factors 21 and 30. Not much different from the results of the second study, Mitsubishi Research Institute (in Hariadi, 2009 ) said if financial factors contribute to success in the workforce by 10 percent, expertise in their fields is 20 percent, networking is 30 percent and soft skills are 40 percent. Furthermore, the survey of the National Association of Colleges and Employees (in Elfindri et al., 2010) states that there are 19 abilities needed in the labor market, including: communication, honesty, cooperation, interpersonal, good work ethic, motivation, adaptation, analytical, computer, organization, detail orientation, leadership, confidence, courtesy, wisdom, achievement index of more than 3.00, creative, humorous, and entrepreneurial abilities. Based on the results of the four studies, it was revealed that empirical success was largely determined by character factors, not intelligence.

Deeper than the determinants of one's success, historian Toynbee (in Lickona, 2012) has observed and the results of 21 important gazettes, 19 faces killed not by conquest from the outside, but by moral decay from within. This means, aside from being a determinant of one's success, empirical character is also known to be a determinant of the survival (future) of a civilization, nation, and/or country. A glimpse into history reminds us, centuries ago, the government of the ancient People's Republic of China was told that it was longing for security from the attack of the Bar-Bar people from the north so that a large wall was built which is now called 'The Great Wall of China'. Physically, this wall is too high to climb, too thick to be dismantled, and too long to be surrounded. However, the history of the Chinese records, during the first 100 years after the wall was built, China has been invaded by Bar-Bar people 3 times. The reason was that the wall gatekeepers could be bribed with large amounts of money by the people of the Bars, so that the people could break in through the wall door. From here, it is clearly illustrated that the problem of the internal character of a nation/state is more dangerous than an enemy attack because this is equivalent to suicide.

Character is ownership of good things (Lickona, 2012). 'Good' can be interpreted as moral values that have objective goodness, namely values that strengthen human dignity and promote the goodness of individuals and society (Lickona, 2012). Character is good values (know goodness, want to do good, real good life, and have good impact on the environment) which are selfcontained and embodied in behavior (National Character Development National Policy 2010-2025, 2010). So, character is a quality that distinguishes between someone who is civilized and not. Whereas, someone is said to have character when he has fulfilled four things, namely knowing good value, wanting to do good, being consistent in doing good deeds, and having a good impact on the environment.

Character society is a future asset of a nation/country. Cicero (in Lickona, 2012) said that in the character of society, the welfare of the nation lies. Deeper, the Indonesian government through the National 
Character Development Policy of 2010-2025 (2010) stressed that the loss of character causes the loss of the nation's next generation. Based on the two quotations, it is clear that seeking for a society to grow and develop into a character with character is an absolute thing that must be done by a nation/country including Indonesia, because only in the character of society, the future of a nation/country can be entrusted. In fact, the health of a nation in the next few centuries, said Lickona (2012) depends on how serious the community is to commit to this calling.

Course are educational institutions outside the school that provide lessons and knowledge or skills in a short time. As one form of non-formal education unit, the course functions as a substitute, enhancer, and complementary to formal education in order to support lifelong education (Law Number 20 of 2003). Courses are held for people who need knowledge, skills, life skills, and attitudes to develop themselves, develop their profession, work, independent business, or continue their education to a higher level (Law Number 20 of 2003). Although the function of the course is as a substitute/supplement/complement to formal education, courses as a sub-system of national education still have the same function as an education unit in the formal pathway in building and forming Indonesian human beings who have one faithful, intelligent, and have good personal qualities (character).

Basic English Course or commonly abbreviated as BEC is an English language education institution founded by Mr. Muhammad Kalend Osen on June 15, 1977 with an address on street of Anyelir Number 8 RT 01 RW XII, Singgahan, Palem, Pare, Kediri, East Java, Indonesia. Growing and developing as a non-formal education unit, BEC appears as a well-known English course institution in the Pare environment. Aside from being touted as the oldest English language course institution (in Pare) as well as the pioneer of the birth of 'English Village Pare', $\mathrm{BEC}$ is also known as an Islamic language course with a strong Islamic nuance, so that there is a nickname 'a course with pesantren taste'. BEC is also known as an institution that is firm and consistent in disciplining its students. In fact, the firmness of BEC educational institutions in applying discipline to trigger the emergence of public judgment that violates the discipline of BEC means ready to be expelled from BEC.

\section{METHOD}

The approach used in this study is a qualitative approach with the aim of obtaining descriptions and descriptions of the internalization of character values. This approach was chosen because the focus in this study relates to relationships and processes so that it requires observation. The type of research used in this study is a case study, which focuses on humans and events. The role of the researcher as a data collector and observer to understand the conditions and obtain information directly at the Educational Institution of the Basics English Course Pare, Kediri, Province of East Java. Sources of data were obtained from key informants, namely the director of the Basic English Course, supported by information from educators and education. The process of collecting data is done by researchers by applying observation, interview, and documentation studies techniques. Then analyzed based on the process of interactive data analysis according to Miles and Huberman which consists of three steps, namely: data reduction, data display, and verification of data or conclusions. The data obtained, checked its validity by: (1) extending the time of research, (2) increasing the research informants, (3) increasing perseverance and thoroughness, (4) triangulating data sources, and (5) utilizing the research documents obtained/owned.

\section{Background of Internalization}

\section{RESULTS}

Like a coin, BEC has two sides. One side as an educational institution and one side as a business. In line with these facts, there are two big interests identified which merge into one and manifest as the background of the internalization of character values at BEC. First, in terms of as an educational institution, the background of the internalization of character values at BEC explicitly refers to the essence of education as a process of transfer of knowledge and the transfer of value. This background is as identified by Mr. Kalend who revealed that yes...in general...we are not the name... although this is not official education, because we want that person to be successful, automatically the character we build...that person, he can realize with a lesson, if he already has that character right, he knows the value. Secondly, from the perspective of a business, the background of internalization of character values at BEC is explicitly referring to the efforts of the founders of BEC in giving more value to the services of English language courses provided so that prospective customers feel interested in using BEC services. This background is as read from Mr. $\mathrm{Fa}$ said that indeed Be-E-Se is basically a business orientation. So, the person who works must have a special characteristic. So, to attract a consumer if we only sell English, that is too much of a move. So we have to have...ee....a reliable program that can be promised to the community, especially our environment, an Islamic environment, so parents will be more confident to put their children to live here, because here...ee...the identity is Islamic teachings, Islamic values, although not taught literally but we teach them the values in the form of daily behavior. It is an economic review; the intention is to make this liken so that it can be trusted by the community. This business background is also considered relevant considering that the founder of BEC is Mr. Kalend once said that this course is my place to eat, my business, where I live.

\section{Internalized Character Values}

Based on Mr. Kalend answer when responding to questions about discipline as a BEC characteristic where Mr. Kalend said emphatically if it was not a characteristic, the actual needs of that person, Be-ESe...just imitating what nature is, not creating, we are utilizing what we see 'ohh...this', 'ohh...people are really like that, really, actually Be-E-Se tuh, not the new inventor...Be-E-Se is following the situation, it can be identified that character values internalized at BEC are the 
same as values characters that are internalized in other educational units. The following is a description of 2 of the 22-character values internalized at BEC Pare Kediri.

One, the value of Islamic religious character. Religion is an attitude and behavior that is obedient in carrying out the teachings of the adhered religion, tolerant of the implementation of worship of other religions. Religious Islam as one of the character values internalized at BEC can be identified massively by embedding the basmalah reading on the outside and hamd on the inside of BEC gate, which is then based on Mr. Fa is known that the embedding of the reading basmalah and hamdalah have coherence with the invitation to always start and end everything with prayer as is usually taught by educators to students in the daily learning and teaching process.

Expressed by Mr. Fa that Mr. Kalend had come to a place, I forgot his name. But, yes, the point is like this, reminding students to read basmalah to come in here, that when we start everything with basmalah then certainly get help from God, and yes...the conclusion, will get convenience. Even though it feels difficult, but the ending will be, we will get convenience. So, it's not enough to be fluent in English, our desire is useful, that's it. Yes, with the...this is just a reminder, but not everyone reads it, but yes...that's the name, right, so this is the hope that students enter this, with reading basmalah, and also reminded we are always grateful, that we are finished and leave, read hamdalah. So, we don't say well, closed with good things.

Two, responsibility is the attitude and behavior of a person to carry out their duties and obligations, which he should do, towards oneself, society, environment (nature, social and culture), state and God Almighty. In line with Mr. Kalend life principles that responsibility must be greater than appearance, responsibility is the next character value which is known to be one of the character values internalized at BEC. This is as reflected in Mr. Adin who said automatic responsibility, like his principle (Mr. Kalend), responsibility must be greater than appearance.

\section{Ways to internalize}

The internalization of character values at BEC in general is carried out through four ways, namely: enforcement of regulations and sanctions, advice, exemplary, and habituation. Referring to the two agreements contained in the warning statement of $\mathrm{Mr}$. Kalend, as the basis of course education at BEC, namely one, if you intend to study at BEC, you must intend to be regulated and two, if you intend to study at BEC but do not want to be regulated, please cancel your intention to study at BEC.

The first way that was applied by the founder of BEC was Mr. Kalend in relation to building the foundation of education at BEC, including the internalization of the values of character that Mr. saw Kalend as the key to exposing BEC students to successfully learn English as Mr. Kalend said that yes, in general, we are not the name...although this is not official education, because we want that person to be successful, automatically the character we build...that person, he can be aware of a lesson, if he already has that character right, he knows the value. The advice as one of the ways for BEC TPK to internalize character values to their students, can be identified through the contents of Mr. speech. Kalend, who is none other than the founder of BEC, is considered to be full of elements of advice in order to strengthen the character of BEC students as reflected in the excerpt from Mr. Kalend who said that to the level of the engineer wel in $\mathrm{Bi}-\mathrm{I}-\mathrm{Si}$ ?

The personality of Sinau Neng Be-E-Se? One, yy yy intens, maintain the intention. Hah, any activity in our lives, according to the Prophet Muhammad (peace be upon him), most importantly it maintains intention. Don't forget, once you have the intention to learn, keep learning. Yes indeed, many things can interfere with that person's intentions. Ashikkk learns, tempted by yellow, green, left, right, confused. Well from English, he thought differently.

Get out of his brain, that's it. So, mandated, maintain intention. Naturally, if we can deviate, we are normal. I admit, it's only natural that we learn that it can be tempted by other things, it's natural. We are human beings. Only, you have to have guidelines. Must return to the original intention. How difficult it would be if we never had a crush on people. It's hard. So, wait a minute. So, thankful that we can know other people. Turn as much optimism into your heart as you learn. Believing will get success. Generate confidence in your heart to achieve success.

Exemplary as one of the ways of BEC TPK in internalizing character values to their students, was explicitly identified through Mr. Ibnu said that because of their attitude, what should I do...must be forced into the term or must speak English, starting from the classroom, the teacher also explained the use of English. Habit as a way of BEC in internalizing character values to its students can be explicitly identified through the application of rules at BEC. For example, at BEC there are rules that require students to wear shoes correctly aka the back should not be stepped on. In practice, to be able to comply with these regulations, students need to be habituated to shoeshine properly.

\section{Support Owned in Internalization of Character Values}

There are two supports that BEC TPK has in internalizing character values at BEC. First, is the warning statement of Mr. Kalend, who emphasized that anyone (BEC students) who did not want to be regulated, was excluded from BEC. Second, is the granting of prerogative or authority by Mr. Kalend to BEC TPK to provide decisive action in the form of student expenditures that do not want to be regulated from BEC.

Both of these supports, explicitly known through the statement of Ms. Nova, said that the answer from Mr. Kalend also remained like that before, he gave us the right, if indeed it cannot be arranged, it would be issued please, for example one class is like there are only five people. No, the most important thing can be arranged and Mr. Ibnu said that actually each of us was given a policy to regulate, if for example there was a child who could not be a diator, it could be issued, without having to discuss with the teacher. If they don't accept it, they may complain to Mr. Kalend, like that. 


\section{DISCUSSION \\ Background of Internalization}

In line with the two status of BEC which is an educational institution and at the same time a business, there are two big interests identified which merge into one and become the background of the internalization of character values at BEC. First, in terms of as an educational institution, the background of the internalization of character values at BEC explicitly refers to the essence of education as a process of transfer of knowledge and the transfer of value. This background is in accordance with the elaboration of the functions and objectives of Indonesian national education which is to build Indonesian human beings who are of the same, intelligent and character as explained in Law Number 20 of 2003 that national education functions to develop abilities and shape character in the intellectual life of the nation. Aims to develop the potential of students to become human beings who believe and fear God Almighty, have noble character, are healthy, knowledgeable, capable, creative, independent, and become democratic and responsible citizens. In addition, this background is also appropriate with educational objectives revealed by Lickona (2012) that based on historical research in all countries of the world, education has two main objectives, namely to guide the younger generation to be intelligent and have virtuous behavior.

Secondly, from the perspective of a business, the background of the internalization of character values at $\mathrm{BEC}$ is explicitly referring to the efforts of the founders of BEC in giving more value to the services of English language courses provided so that prospective customers feel interested in using BEC services. This background is in accordance with one of the points of the competitive strategy in the form of two basic types of competitive advantage that Porter put forward (in Suryana, 2006), namely low cost and differentiation. Successful companies with low cost strategies have the ability to design products and markets that are more efficient than competing companies. Whereas what is meant by differentiation is the ability to produce unique goods or services and have more value or added value for buyers in the form of product quality, special characteristics, and other services.

\section{Internalized Character Values}

Character values identified were internalized at BEC based on exposure to data from research results including religious Islam, responsibility, discipline, independence, clean, neat, friendly, honest, hard work, respect for achievement, tolerance, creative, democratic, curiosity, love for the country, love to read, care for the people, care for the environment, simple, courageous, fair, and polite and courteous. The overall values are in accordance with the 18 character values offered by the Ministry of National Education to the managers of educational institutions to be educated/taught to students, 18 these character values are religious, honest, tolerant, disciplined, hard work , creative, independent, democratic, curiosity, national spirit, love for the country, respect for achievement, friendship, peace of mind, love to read, caring for the environment, social care, and responsibility (Ministry of National Education, 2010). Likewise, in accordance with the 9 anti-corruption values mentioned by the Ministry of Education and Culture (2011), namely honesty, caring, independence, discipline, responsibility, hard work, simplicity, courage and justice.

\section{Ways to internalize}

The internalization of character values at BEC, in general, is carried out in four ways, namely: enforcement of regulations and sanctions, advice, exemplary, and habituation. If it is associated with the internalization stage proposed by Muhaimin (1996), namely: (1) the stage of value transformation, namely a process carried out by educators in informing good and bad values where at this stage there is only verbal communication between educators and students, (2) the transaction transaction stage, which is a stage of value education by conducting two-way communication between educators and students in the form of reciprocal interaction, and (3) the transinternalization stage, which is a stage that is far deeper than the transaction stage where not only done by verbal communication but also mental and personality attitudes, at this stage personality communication plays an active role, so how to internalize character values through the application of rules and sanctions is included as a category of processes that occur in the transinternalization stage, advice is included as a process category which occurs in stage $\mathrm{t}$ value transformation, exemplary and habituation is included as a process category that occurs in value transactions.

\section{Support Owned in Internalization of Character Values}

There are two supports that BEC TPK has in internalizing character values at BEC. First, is the warning statement of Mr. Kalend which is the basis of learning at BEC which confirms that anyone (BEC students) who do not want to be regulated, then is excluded from BEC. Second, is the granting of prerogative or authority by Mr. Kalend to BEC TPK to provide decisive action in the form of student expenditures that do not want to be regulated from BEC.

If combined with the results of previous studies conducted by Widiasari (2013) which found that the supporting factors in the transformation of the culture of discipline of students in SMK PGRI 3 Malang are clear rules, examples from educators, supporting facilities, and information technology that the school has already advanced, the similarity between support in the cultural transformation of disciplines of students at SMK PGRI 3 Malang and support in internalizing character values at BEC Pare Kediri is located in the existence of clear rules. Whereas, when combined with the results of research conducted by Herfianto (2014) who found that the supporting factors for character education management at SD Islam Surya Buana Malang included collaboration between educators, participation of students and parents of students. The form of support from principals and educators to achieve the success of character education at Surya Buana Islamic Elementary School in Malang includes principals and educators working together to foster and supervise students in schools to achieve the goal of forming the character of students who have moral 
character, the similarity between support in character education management at Surya Buana Islamic Elementary School Malang and support in internalizing character values at BEC Pare Kediri is located in good cooperation between the institution leadership and the institution TPK.

\section{CONCLUSION}

The conclusions of the study show: (1) background of internalization is the essence of education and business, (2) internalized character values include: religious Islam, responsibility, discipline, independent, clean, neat, friendly, honest, hard work, respect for achievement, tolerance, creative, democratic, curiosity, love for the country, love to read, care for the social, care for the environment, simple, courageous, fair and polite and polite, (3) ways to internalize character values is the enactment of regulations and sanctions, advice, exemplary, and habituation, (4) the support they have in internalizing character values is a warning statement to Mr. Kalend and the granting of prerogative or authority in the form of student expenditures that do not want to be regulated by BEC, (5) constraints faced in internalizing character values include: education in families that implement minimal rules, lack of commitment of students to be regulated, education in Educational Institutions that implement minimal rules, variations in the age of students, the intention of students to change, and the intention or motivation of learners at BEC, (6) the strategies used in utilizing support are to be wise, and (7) strategies used in Overcoming obstacles is a personal (face to face) approach while being advised, making agreements with students, and doing self-introspection.

\section{REFERENCES}

[1] Agustina, N. E., Sumarsono, R. B., \& Gunawan, I. (2018). Implementation of School and Community Relationship Techniques (A Case Study in SDN Karangbesuki 2 Malang, Indonesia). In 1st International Conference on Early Childhood and Primary Education (ECPE 2018). Atlantis Press.

[2] Akbar, A. I. (2000). Character Education. USA: Harvard University.

[3] Bafadal, I., Juharyanto, J., Nurabadi, A., \& Gunawan, I. (2018a). Principal Leadership and its Relationship with Student Learning Achievements: A Regression Analysis. In 3rd International Conference on Educational Management and Administration (CoEMA 2018). Atlantis Press.

[4] Bafadal, I., Nurabadi, A., \& Gunawan, I. (2018b). The Influence of Instructional Leadership, Change Leadership, and Spiritual Leadership Applied at Schools to Teachers' Performance Quality. In International Conference on Education and Technology (ICET 2018). Atlantis Press.

[5] Burhanuddin. (1994). Analisis Administrasi Manajemen dan Kepemimpinan Pendidikan. Jakarta: PT Bumi Aksara.

[6] Development of Cultural and National Character Education: School Guidelines for 2010. Reforming Teachers (online), (http://gurupembaharu.com), accessed January 20, 2016.

[7] Elfindri, M. Basri, W., Poltak, T., Fitri, Y., Elfa, E. Z., Ristapawa, I. (2010). Soft Skills for Educators. Jakarta: Baduose Media.
[8] Government of the Republic of Indonesia. 2006. Law of the Republic of Indonesia Number 20 of 2003 concerning the National Education System. Bandung: Media focus.

[9] Gunawan, I. (2013). Statistika untuk Kependidikan Sekolah Dasar. Yogyakarta: Penerbit Ombak Yogyakarta.

[10] Gunawan, I. (2016). Pengantar Statistika Inferensial. Jakarta: Rajawali Pers.

[11] Gunawan, I., Kusumaningrum, D. E., Triwiyanto, T., Zulkarnain, W., Nurabadi, A., Sanutra, M. F. A., ... \& Yuantika, E. A. F. (2018a). Hidden Curriculum and Character Building on Self-Motivation based on K-means Clustering. In 2018 4th International Conference on Education and Technology (ICET) (pp. 32-35). IEEE.

[12] Gunawan, I., Kusumaningrum, D. E., Triwiyanto, T., Zulkarnain, W., \& Nurabadi, A. (2018b). Hidden Curriculum and its Relationship with the Student Character Building. In 3rd International Conference on Educational Management and Administration (CoEMA 2018). Atlantis Press.

[13] Gunawan, I., Kusumaningrum, D. E., Triwiyanto, T., Zulkarnain, W., \& Nurabadi, A. (2018c). Pengaruh Kurikulum Tersembunyi terhadap Motivasi Diri Mahasiswa. Prosiding Seminar Nasional Pendidikan, Tema: Mendidik Cerdas Generasi Digital, Fakultas Ilmu Pendidikan Universitas Negeri Malang, Malang, 4 Oktober 2018, hlm. 90-97.

[14] Hadi, S., Gunawan, I., \& Dalle, J. 2018. Statistika Inferensial: Teori dan Aplikasinya. Jakarta: Rajawali Pers.

[15] Hardika, H., Aisyah, E. N., \& Gunawan, I. (2018). Facilitative Learning to Improve Student Learning Creativity. In 3rd International Conference on Educational Management and Administration (CoEMA 2018). Atlantis Press.

[16] Hariadi. (2009). Soft Skill and Student Creativity Program. Campus Generation, 2 (2), 119-134. From http://jurnal.unimed.ac.id/2012/index.php/gk/article/ viewFile / 7070/6050.

[17] Harmini, S., Kartini, H., \& Gunawan, I. (2017). Filsafat dan Teori Pendidikan. Malang: Penerbit Universitas Negeri Malang, Penerbit UM Press.

[18] Herfianto, F. D. (2014). Character Education Management at SD Islam Surya Buana Malang. Unpublished thesis. Malang: FIP Malang State University.

[19] Hidayah, N., Hardika, Hotifah, Y., Susilawati, S. Y., \& Gunawan, I. (2017). Psikologi Pendidikan. Malang: Penerbit Universitas Negeri Malang, Penerbit UM Press.

[20] Kurniati, I. (2007). Success Factor, (Online), (www.pangudiluhur.org), accessed March 11, 2017.

[21] Kusmintardjo, \& Gunawan, I. 2017. Manajemen Layanan Khusus. Malang: Penerbit Universitas Negeri Malang, Penerbit UM Press.

[22] Kusumaningrum, D. E., Sumarsono, R. B., \& Gunawan, I. (2017a). Pemberdayaan Tenaga Administrasi Sekolah Menengah Pertama Berbasis Pesantren. In Prosiding Seminar Nasional Pendidikan Sinergitas Keluarga, Sekolah, dan Masyarakat dalam Penguatan Pendidikan Karakter, Fakultas Ilmu Pendidikan Universitas Negeri Malang, Malang (Vol. 16, pp. 127-138).

[23] Kusumaningrum, D. E., Sumarsono, R. B., \& Gunawan, I. (2017b). Problematika Pemberdayaan dan Pengembangan Sumber Daya Manusia di Sekolah Menengah Pertama Berbasis Pesantren. Ilmu Pendidikan: Jurnal Kajian Teori dan Praktik Kependidikan, 2(2), 139-150.

[24] Kusumaningrum, D. E., Sumarsono, R. B., \& Gunawan, I. (2018). Teachers Empowerment of Pesantren-Based Junior High School East Java Province Indonesia. Journal of Social Sciences and Humanity Studies, 4(3), 29-33.

[25] Lickona, T. (2012). Character Matters. Juma A. W. Translation Jakarta: PT Earth Literacy. 2004. 
[26] Ministry of Education and Culture. (2011). AntiCorruption Education for Universities. Jakarta: Ministry of Education and Culture.

[27] Muhaimin. (1996). Teaching and Learning Strategies. Surabaya: media image.

[28] Nurabadi, A., Sucipto, S., Juharyanto, J., \& Gunawan, I. (2018). The Implementation of Education Management Standards in the School Laboratory State University of Malang for Improving Educational Quality. In 3rd International Conference on Educational Management and Administration (CoEMA 2018). Atlantis Press.

[29] Pertiwi, A. K., Cahyani, S. S. A., Diana, R. C., \& Gunawan, I. (2017). Kepemimpinan Berbasis Nilai dan Etika: Suatu Kajian Interaksi Simbolik Kyai dan Santri. In Prosiding Seminar Nasional Pendidikan: Sinergitas Keluarga, Sekolah, dan Masyarakat dalam Penguatan Pendidikan Karakter, Universitas Negeri Malang, Malang (Vol. 16, pp. 1-9).

[30] Pertiwi, A. K., Cahyani, S. S. A., Diana, R. C., \& Gunawan, I. (2018). The Leadership of Kyai: A Descriptive Study. In 3rd International Conference on Educational Management and Administration (CoEMA 2018). Atlantis Press.
[31] Sobri, A. Y., Bafadal, I., Nurabadi, A., \& Gunawan, I. (2018). Development of Mentoring Modules Based on Self-Reflection for Beginner Principal. In 3rd International Conference on Educational Management and Administration (CoEMA 2018). Atlantis Press.

[32] Sudharta, V. A., Mujiati, M., Rosidah, A., \& Gunawan, I. (2017). Gaya Kepemimpinan Kepala Sekolah dalam Perspektif Psikologi. JMSP: Jurnal Manajemen dan Supervisi Pendidikan, 1(3), 208-217.

[33] Sultoni, Gunawan, I., \& Sari, D. N. (2018b). The Internalization of Character Values to Students: A Descriptive Study. In International Conference on Education and Technology (ICET 2018). Atlantis Press.

[34] Sultoni, S., Gunawan, I., \& Ningsih, S. O. (2018a). Descriptive Study of Efforts Integrates Character Values to Students. In 3rd International Conference on Educational Management and Administration (CoEMA 2018). Atlantis Press.

[35] Suryana. (2006). Entrepreneurship. Jakarta: PT Salemba Empat.

[36] Widiasari, D. (2013). Transformation of Discipline Culture of Students at SMK PGRI 3 Malang. Unpublished thesis. Malang: FIP Malang State University. 